\title{
Reproductive dysfunction and associated pathology in women undergoing military training
}

\author{
Robert M Gifford, ${ }^{1,2}$ R M Reynolds, ${ }^{1}$ J Greeves, ${ }^{3}$ R A Anderson, ${ }^{4}$ D R Woods ${ }^{2,5,6,7}$
}

\begin{abstract}
${ }^{1}$ British Heart Foundation Centre for Cardiovascular Science, Queen's Medical Research Institute, Edinburgh, UK ${ }^{2}$ Defence Medical Services, Lichfield, UK

${ }^{3}$ Army Personnel Research Capability, Army HQ, Andover, UK

${ }^{4} \mathrm{MRC}$ Centre for Reproductive Health, Queen's Medical Research Institute, Edinburgh, UK

${ }^{5}$ Research Institute for Sport, Physical Activity and Leisure, Leeds Beckett University, Leeds, UK

${ }^{6}$ Northumbria and Newcastle NHS Trusts, Wansbeck General and Royal Victoria Infirmary,

Newcastle, UK

${ }^{7}$ University of Newcastle,

Newcastle upon Tyne, UK
\end{abstract}

\section{Correspondence to} Sqn Ldr Robert M Gifford, British Heart Foundation Centre for Cardiovascular Science, QMRI, Room C3.01, 47 Little France Avenue, Edinburgh EH16 4TJ, UK; r.gifford@ed.ac.uk

Received 6 October 2016 Revised 15 December 2016 Accepted 27 January 2017 Published Online First 17 February 2017

\section{ABSTRACT}

Introduction Evidence from civilian athletes raises the question of whether reproductive dysfunction may be seen in female soldiers as a result of military training. Such reproductive dysfunction consists of impaired ovulation with or without long-term subfertility.

Methods A critical review of pertinent evidence following an extensive literature search.

Results The evidence points towards reduced energy availability as the most likely explanation for exerciseinduced reproductive dysfunction. Evidence also suggests that reproductive dysfunction is mediated by activation of the hypothalamic-pituitary-adrenal axis and suppression of the hypothalamic-pituitary-gonadal axis, with elevated ghrelin and reduced leptin likely to play an important role. The observed reproductive dysfunction exists as part of a female athletic triad, together with osteopenia and disordered eating. If this phenomenon was shown to exist with UK military training, this would be of significant concern. We hypothesise that the nature of military training and possibly field exercises may contribute to greater risk of reproductive dysfunction among female military trainees compared with exercising civilian controls. We discuss the features of military training and its participants, such as energy availability, age at recruitment, body phenotype, type of physical training, psychogenic stressors, altered sleep pattern and elemental exposure as contributors to reproductive dysfunction.

Conclusions We identify lines of future research to more fully characterise reproductive dysfunction in military women and suggest possible interventions that, if indicated, could improve their future well-being.

\section{INTRODUCTION}

Understanding of the relationship between exercise and reproduction has significantly evolved in recent years. 'Athletic amenorrhoea' has been observed in civilian athletes for many decades, ${ }^{1}{ }^{2}$ while more recently studies have demonstrated a high prevalence of amenorrhoea in basic military training. ${ }^{3} 4$ Unlike athletics, military training is not intended to optimise performance in a specific sport and is more task-orientated. For example, exposure to extremes of temperature, psychological stressors and prolonged, heavy load carriage are important for military output and may carry physical risks (eg, stress fracture) that civilian athletic training might not. ${ }^{5} 6$ This review focuses predominantly on basic military training, which generally lasts several months. Most basic military trainees are adolescents in their late teens, presenting additional challenges to reproductive homeostasis. ${ }^{4} 7$

Consideration of reproductive dysfunction in the military is important not only due to the potential

\section{Key messages}

- Evidence suggests that reproductive dysfunction could be prevalent among female military trainees.

- The pathology associated with such reproductive dysfunction is associated with reduced energy intake and could predispose women to injury.

- Evidence from civilian athletes points to reduced energy availability as the key cause. Other factors specific to military training may also be likely to contribute.

- Further research could be beneficial in assessing the scale of reproductive dysfunction in UK military women and understanding its aetiology.

- There are a number of interventions that, if necessary, could theoretically reduce or even prevent significant reproductive dysfunction and its associated pathologies.

for sustained subfertility in individuals but more widely as a surrogate of non-reproductive pathologies that might impact operational effectiveness. Potential reproductive dysfunction, when understood, might be prevented or at least the risk reduced.

The purpose of this paper is to explore what is currently known about the scale and aetiology of reproductive dysfunction in military training and the impact of associated conditions. As a preface to this, methods used to measure female reproductive function are described, and hypothalamic adaptations to exercise and the role of brain energy availability are discussed. Other associated pathologies are described, and military-specific risk factors are also considered. The case for further research and potential strategies for prevention is outlined.

\section{METHODS}

Articles published from 1939 to 2016 were identified using PubMed, Ovid Medline and Google Scholar for combinations of the following search terms (truncated): military, exercise, sport, physical activity, endocrine, reproductive, menstrual, ovulation. Bibliographies of relevant articles were reviewed for relevant publications, and subsequent citations (identified through Google Scholar) were also included.

Reproductive dysfunction is defined here as any endocrine imbalance that could impair normal ovulatory menstrual cycles. Military training is defined 
as the necessary means for initiation into combat roles ('basic training') or to maintain generic soldiering skills ('career-long training') and places significant demands on the trainee physically and psychologically. ${ }^{56}$

\section{MEASURING REPRODUCTIVE HEALTH}

Dysfunction of reproductive homeostasis is complex. The terms used to describe it are explained in Table $1{ }^{8}$ Regular eumenorrhoeic cycles do not confirm ovulation and are by no means a guarantee of normal reproductive function. ${ }^{9}$ An anovulatory cycle may be short, normal or long, but no oocyte is released. In military studies, menstrual function has been assessed using questionnaires, ${ }^{4}{ }^{10-12}$ as in civilian athlete studies. ${ }^{13}{ }^{14}$ Such questionnaires generally involve an assessment of menstrual onset, duration and frequency constructed by the investigators, defining clinical menstrual disorders as outlined in Table 1. No study stated if the questionnaires used to determine menstrual regularity in athletes were validated. Questionnaires can be misleading due to cycle duration variability seen typically in athletes, and the observation of menstrual regularity does not signify normal ovulation. ${ }^{15} 16$

Repeated ultrasound examination with serum hormone assay are the most accurate means of demonstrating the development and disappearance of an ovarian follicle. While the former is

Table 1 Terms used to describe reproductive dysfunction in athletes 891417

\begin{tabular}{ll}
\hline Hypothalamic-pituitary- & $\begin{array}{l}\text { The hormonal chain of reproductive homeostasis. } \\
\text { gonadal axis }\end{array}$ \\
negative feedback, the hypothalamus releases \\
gonadotropin-releasing hormone, which stimulates \\
luteinising hormone and follicle-stimulating \\
hormone release from the pituitary, which in turn \\
stimulate progesterone and oestrogen release from \\
the ovaries (Figure 2). \\
The first half of the menstrual cycle, manifested by \\
the onset of menstrual flow. Oestradiol levels are \\
initially low then rise markedly towards ovulation. \\
Progesterone is low throughout \\
The second half of the menstrual cycle, initiated by \\
a surge in luteinising hormone and ovulation. \\
Normally associated with a marked rise in \\
progesterone from follicular levels, and continuing \\
oestradiol secretion.
\end{tabular}

too invasive to have gained widespread use as a research tool, ${ }^{18}$ a sustained, elevated progesterone in the luteal phase is often accepted as evidence that ovulation has taken place. ${ }^{19}$ The luteal phase may be shortened or absent, even within a normal length menstrual cycle, when a predetermined midluteal progesterone cut-off is not reached (a 'luteal phase defect' (LPD), Table 1). ${ }^{18}$ Due to difficulty demonstrating the midluteal point in athletes with variable cycle lengths, serial samples are needed, which can be challenging in large numbers. Measuring urinary pregnanediol glucuronide (PDG), a metabolite of progesterone, offers greater convenience than blood sampling. While not routinely available in clinical practice, in research it is normally the measurement of choice. ${ }^{18} 20$

\section{ASSESSING THE PREVALENCE OF MENSTRUAL DISORDERS IN MILITARY TRAINING}

The spectrum of reproductive function and dysfunction is illustrated in Figure 1. The studies describing the prevalence of reproductive dysfunction associated with military training are summarised in Table 2. ${ }^{4} 10-122122$ A wide range of prevalence is reported and the definitions used differ, making meaningful interpretation difficult. For example, Friedl et al and Lauder et al identify different amenorrhoeic timeframes, whereas Schneider assesses a continuum of irregularity. The studies appear to be subject to selection bias; for example, Lauder et $a l^{23}$ reported that reserve officer cadets were too busy to undertake a survey and were thus excluded from further analysis. Soldiers receiving a mail survey might be more likely to have responded if they had undergone menstrual disturbance. ${ }^{10}$ Recall bias can also hamper results since menstrual disturbances are reported more frequently with short-term rather than longterm recall (which was used in all other studies). None of the studies describe the actual questions asked, so it is unclear if some of the questions were 'leading' ${ }^{11}$ Such problems arising with surveys are not addressed, for example, by measuring serial urine PDG.

Given the paucity of data on the prevalence of reproductive dysfunction in female military personnel, we consider the civilian athletic literature. In a systematic review of all athletic disciplines, Gibbs et $a l^{14}$ report the prevalence of menstrual dysfunction to be $1-60 \%$ (34 studies, $n=5607$ ). ${ }^{14}$ Such a wide variation in the prevalence of menstrual disturbance could be accounted for by the specific population (eg, factors such as selection bias and under-reporting) or methodological variations. However, it is clear that the prevalence of reproductive dysfunction among a training population is significantly greater than in the general population, where the prevalence of amenorrhoea ranges from $2 \%$ to $5 \% .^{24} 25$

\section{HORMONAL CONTRACEPTION}

A significant challenge to estimating the prevalence of reproductive dysfunction is presented by hormonal contraceptives (Table 2). The use of hormonal contraceptives can be particularly high in soldiers, and in a recent review has been shown to range from $16 \%$ to $34 \%$ for oral contraceptives, $4 \%$ to $11 \%$ for injectable medroxyprogesterone, $3 \%$ to $9 \%$ for the hormonal patch $2 \%$ implants and $0 \%$ to $3 \%$ for intrauterine devices. The use of all forms of hormonal contraceptive is higher in soldiers when deployed. ${ }^{26}$

\section{HYPOTHALAMIC ADAPTATIONS TO EXERCISE \\ The female hypothalamic-pituitary-gonadal axis in exercise}

The response of the female hypothalamic-pituitary-gonadal (HPG) axis to exercise and stress can more aptly be described as 


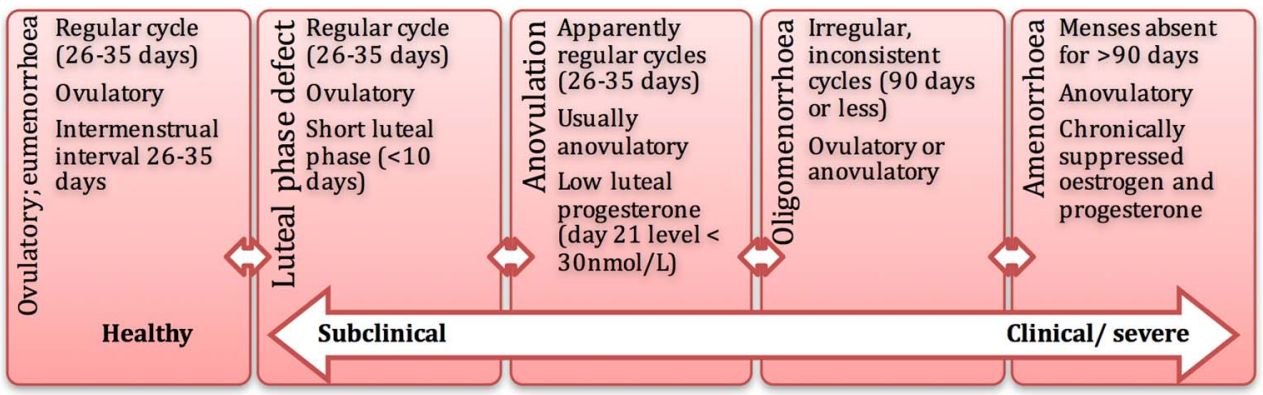

Figure 1 Spectrum of reproductive function and dysfunction observed in athletes, adapted from review by Mallinson, De Souza. ${ }^{8}$ Menstrual health exists at one end of a continuum (represented by the arrow), ranging from subtle, subclinical adaptations such as shortening of the luteal phase, to severe clinical amenorrhoea.

Table 2 Comparison of relevant studies assessing menstrual disturbance in military trainees

\begin{tabular}{|c|c|c|c|c|c|}
\hline Study & Design & Setting, participants & Qualitative outcomes & $\begin{array}{l}\text { Hormonal } \\
\text { contraceptive usage }\end{array}$ & Prevalence reported \\
\hline $\begin{array}{l}\text { Anderson } \\
(1979)^{22 *}\end{array}$ & $\begin{array}{l}\text { USMA, long-term } \\
\text { recall }\end{array}$ & $\begin{array}{l}\text { Freshmen commencing } \\
1977, \mathrm{n}=88 \text {, age } N R\end{array}$ & $\begin{array}{l}\text { 'Secondary amenorrhoea' (duration not } \\
\text { defined) }\end{array}$ & NR & $\begin{array}{l}\text { Amenorrhoea } \\
75 \% \text { at } 1 \text { month } \\
45 \% \text { at } 4 \text { months } \\
8 \% \text { at } 12 \text { months }\end{array}$ \\
\hline $\begin{array}{l}\text { Anderson } \\
(1979)^{22 *}\end{array}$ & $\begin{array}{l}\text { USMA, long-term } \\
\text { recall }\end{array}$ & $\begin{array}{l}\text { Freshmen commencing } \\
1976, n=70 \text {, age NR }\end{array}$ & $\begin{array}{l}\text { 'Secondary amenorrhoea' (duration not } \\
\text { defined) }\end{array}$ & NR & $\begin{array}{l}\text { Amenorrhoea } \\
73 \% \text { at } 1 \text { month, } \\
41 \% \text { at } 6 \text { months, } \\
29 \% \text { at } 9 \text { months, } \\
20 \% \text { at } 12 \text { months }\end{array}$ \\
\hline $\begin{array}{l}\text { Welch } \\
(1989)^{21 *}\end{array}$ & $\begin{array}{l}\text { USMA freshmen and } \\
\text { sophomore, } \\
\text { long-term recall }\end{array}$ & $\begin{array}{l}n=65 \text { (class of 1990), } \\
n=45 \text { (class of 1991), age } \\
\text { NR; excluded those with } \\
\text { prior menstrual irregularity }\end{array}$ & $\begin{array}{l}\text { 'Menstrual irregularity, secondary } \\
\text { amenorrhoea'(duration not defined) }\end{array}$ & $\begin{array}{l}\text { NR (these women } \\
\text { were excluded) }\end{array}$ & $\begin{array}{l}\text { Menstrual irregularity: } \\
68 \%(1990), 72 \%(1991) \\
\text { Resumption of normal } \\
\text { menses: } \\
78 \% \text { after first year (1990) } \\
26 \% \text { during first year (1991) }\end{array}$ \\
\hline $\begin{array}{l}\text { Friedl et al } \\
(1992)^{10}\end{array}$ & $\begin{array}{l}\text { Mail shot survey to } \\
\text { all } 2462 \text { focused on } \\
\text { self-reported stress } \\
\text { fracture }\end{array}$ & $\begin{array}{l}\text { US Army soldiers in Fort } \\
\text { Lewis, Washington, } \\
\mathrm{n}=1630 \text {, median age } 24 \\
\text { (IQR 18-52) years }\end{array}$ & $\begin{array}{l}\text { Amenorrhoea-no menses } 6 \text { months in the } \\
\text { absence of pregnancy }\end{array}$ & $34.9 \%$ & Amenorrhoea 14.9\% \\
\hline $\begin{array}{l}\text { Lauder } \\
(1997)^{23}\end{array}$ & USMA, questionnaire & $\begin{array}{l}\text { USMA reserve officer } \\
\text { training camp cadets, June } \\
1996-n=310 \text { mean age } \\
21.5 \text { (SD 1.9) years }\end{array}$ & $\begin{array}{l}\text { 'Occasionally skipped periods', 'only a few } \\
\text { times per year' }\end{array}$ & NR & $\begin{array}{l}\text { 'Occasionally skipping } \\
\text { periods' } 12 \% \text {, 'only a few } \\
\text { times per year' } 5 \%\end{array}$ \\
\hline $\begin{array}{l}\text { Schneider } \\
\text { et al } \\
(1999)^{4}\end{array}$ & $\begin{array}{l}\text { USMA, long-term } \\
\text { recall questionnaire }\end{array}$ & $\begin{array}{l}\text { USMA, } n=158, \text { mean } 18.4 \\
(\text { SD 0.81) years }\end{array}$ & Regularity 'increased or decreased' & $\begin{array}{l}\text { NR (these women } \\
\text { were excluded) }\end{array}$ & $\begin{array}{l}48.2 \% \text { decreased frequency, } \\
10.1 \% \text { increased }\end{array}$ \\
\hline $\begin{array}{l}\text { Lauder et al } \\
(1999)^{12}\end{array}$ & USMA, interview & $\begin{array}{l}\text { USMA, active duty cadets, } \\
n=423 \text {, mean age } 27.5 \text { (SD } \\
\text { 7.7) years }\end{array}$ & $\begin{array}{l}\text { Oligomenorrhoea }-<9 \text { menses in } \\
12 \text { months; amenorrhoea }-\geq 3 \text { previous } \\
\text { cycle equivalents }\end{array}$ & $\begin{array}{l}24.6 \% \text { of the } 33.6 \% \\
\text { who met eating } \\
\text { disorder screening } \\
\text { criteria }\end{array}$ & $\begin{array}{l}2.1 \% \text { amenorrhoea, } 3.3 \% \\
\text { oligomenorrhoea }\end{array}$ \\
\hline $\begin{array}{l}\text { Schneider } \\
\text { et al } \\
(2003)^{11}\end{array}$ & $\begin{array}{l}\text { USMA, short-term } \\
\text { recall by email }\end{array}$ & $\begin{array}{l}\text { USMA, } n=116 \text { freshmen, } \\
\text { mean age } 18.4(S D \\
0.81 \text { ) years }\end{array}$ & $\begin{array}{l}\text { Menstrual irregularity-percentage of cycles } \\
\text { outside } 21-45 \text { days (moderate } \leq 25 \% \text {, } \\
\text { severe } 26-50 \% \text {, extremely severe }>50 \% \text {; } \\
\text { mild: }>7 \text { day variation in cycle) }\end{array}$ & $\begin{array}{l}\text { NR (these women } \\
\text { were excluded) }\end{array}$ & $\begin{array}{l}\text { Regular: } 1.7 \% \text {; irregular- } \\
\text { mildly } 10.3 \% \text {, moderately } \\
35.3 \% \text {, severely } 30.2 \% \text {, } \\
\text { extremely } 22.4 \%\end{array}$ \\
\hline
\end{tabular}

*Anderson and Welch hypothesise that the pattern of initially high prevalence of amenorrhoea, consistently falling in both studies, was due to psychological and physiological stress, which subsided as training progressed.

NR, not reported; USMA, United States Military Academy, West Point, New York.

a functional adaptation than a disease process, and indeed the term 'functional hypothalamic amenorrhoea' (FHA) is often used (Table 1)..$^{8} 18$

The pattern of HPG adaptation seen varies by activity type and may be influenced by whether the physical characteristics of athletes are lean or non-lean (Table 1). In a systematic review, the prevalence of menstrual disturbance was higher in lean compared with non-lean sports $(1-28 \%$ vs $0-17 \%$, five studies, $\mathrm{n}=1032$, no $\mathrm{p}$ value given). ${ }^{14}$ However, the physical characteristics required for military roles are less dichotomous, involving a combination of muscle strength and endurance, power and aerobic fitness.

The purported adaptations of the HPG axis to exercise in lean and non-lean athletes are summarised in Figure 2. Suppression of the entire HPG axis in athletes from lean sports contrasts with hyperandrogenism and increased luteinising hormone (LH):follicle-stimulating hormone (FSH) ratio seen in athletes from non-lean sports. In the latter, it is not clear if 


\section{Lean sports $\quad$ Non-lean sports}

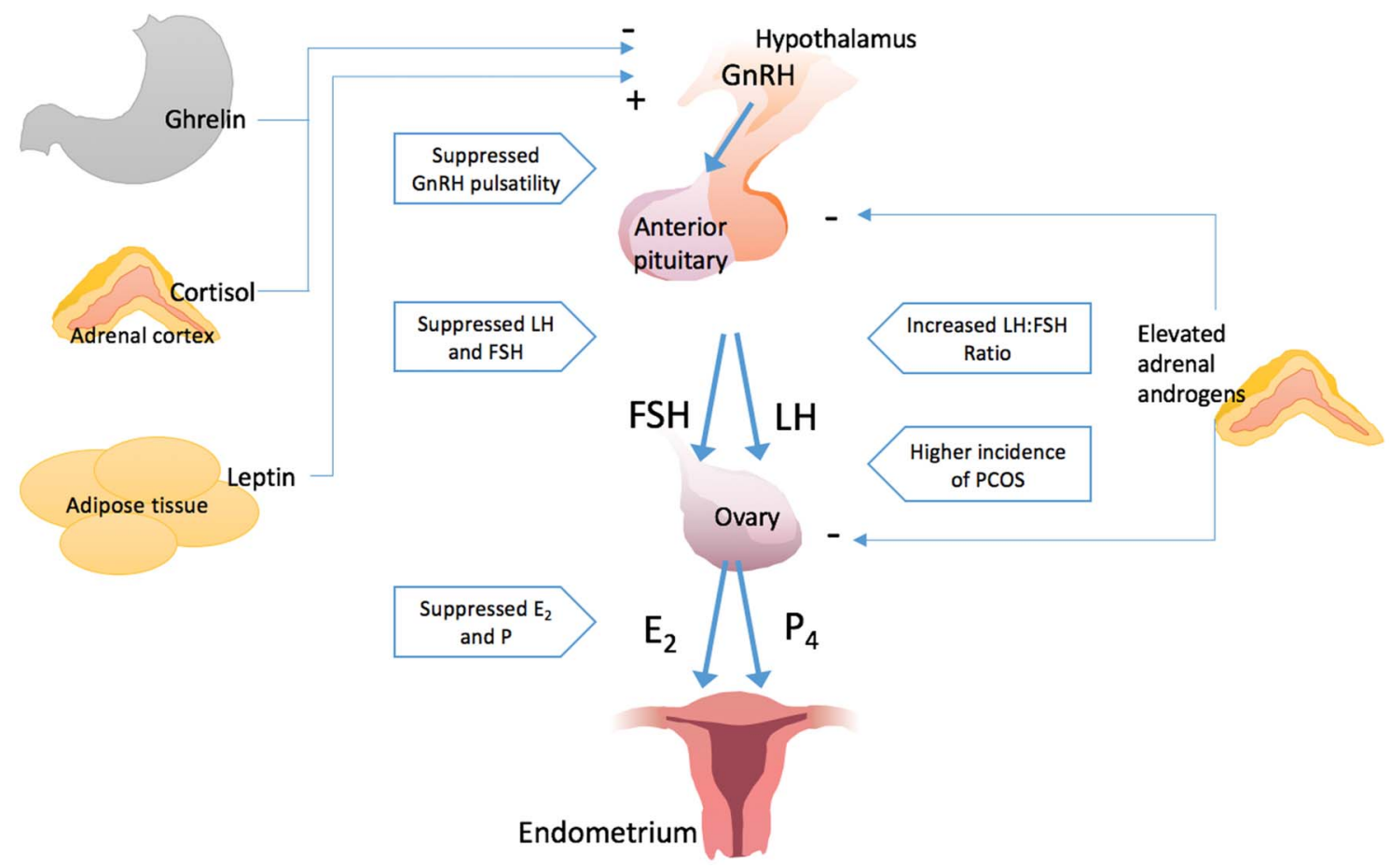

Figure 2 Simplified comparison of hormonal interactions with the hypothalamic-pituitary-gonad axis in athletes undertaking lean and non-lean sports. ${ }^{112-114}$ In athletes undertaking lean sports, reproductive dysfunction is characterised by elevated cortisol and ghrelin and reduced leptin. Suppression of normal pulsatile gonadotropin-releasing hormone $(\mathrm{GnRH})$ release reduces pituitary follicle-stimulating hormone (FSH) and luteinising hormone $(\mathrm{LH})$ release, altering ovarian follicle development, which reduces $E_{2}$. Failure of ovulation results in low $P$. This prolongs the follicular phase leading to ineffective, shortened or absent luteal phases. In non-lean sports, the LH:FSH ratio tends to be increased, androgen levels are elevated and there is a propensity to polycystic ovarian syndrome (PCOS). High levels of androgens may lead to a blunted LH surge and direct impairment of follicular development. $E_{2}$, Estradiol; P4, Progesterone; FSH, follicle stimulating hormone; LH, luteinising hormone; GnRH, Gonadotrophin releasing hormone; PCOS polycystic ovarian syndrome.

hyperandrogenism is a consequence of the training or a result of self-selection. It appears that the effect of training on reproductive function in non-lean sports is less extensively studied. ${ }^{27}$

\section{Interplay between energy availability, stress and reproductive dysfunction in exercising women}

Three distinct hypotheses have emerged to explain the reproductive dysfunction observed in athletes. The body composition hypothesis was based on the observed correlation that menstrual function is lost below a threshold of fat mass, as is observed in women with anorexia nervosa. ${ }^{28}$ However, subsequent studies observed a range of body size and composition in both eumenorrhoeic and amenorrhoeic athletes. ${ }^{29-31}$ The 'exercise stress hypothesis', that activation of the hypothalamic-pituitaryadrenal (HPA) axis leads to amenorrhoea, ${ }^{1}$ was based on the observation that exercise is associated with elevated cortisol levels. ${ }^{17}$ This was thought to explain the observations of Nagata et $a l,{ }^{32}$ who documented amenorrhoea in most Japanese nursing students during their highly stressful term, which resolved during the summer holidays. However, studies failed to control for the energy cost of exercise and the way the exercise was implemented experimentally. ${ }^{17}$ 33-36

The most prominent hypothesis is that of reduced energy availability (defined in Table 1), emerging from the work of Winterer et $\mathrm{al}^{37}$ in the $1980 \mathrm{~s}$, who proposed mammals partition energy hierarchically across six processes in the following order: cellular maintenance, thermoregulation, locomotion, growth, reproduction and storage. Where fuel is spent on one process, such as locomotion, it is unavailable for another, reproduction. ${ }^{38}$ It is postulated that inadequate energy availability to reproductive centres in the hypothalamus leads to HPG axis disruption. $^{30}$

Loucks et $a l^{17}$ performed a series of short studies comparing sedentary and active eumenorrhoeic women, in whom energy intake was manipulated to limit energy availability. Over five consecutive days of exercise, limiting energy intake resulted in suppressed LH pulsatility, while exercise without dietary restriction had significantly less effect. The question remained: does energy availability exert this effect per se or is another component of exercise responsible? Work by Williams et $a l^{39}$ delineated these factors; in rhesus monkeys with exercise-induced amenorrhoea, dietary supplementation restored normal menstruation against controls. The same effect was shown in humans in laboratory studies, supporting the hypothesis that exercise per se has no effect on the hypothalamus beyond that of decreasing energy availability. ${ }^{40} 41$

A study in arduous US Army Rangers controlled for the metabolic impact of exercise in a field training environment. Restricted diets (5000 and $2000 \mathrm{kcal}$ per day on alternate days) were given to Rangers undergoing arduous training, alongside heat, cold and psychological stressors (soldiers were exposed to four 2-week phases in desert, forest, mountain and swamp environments). ${ }^{42} \mathrm{LH}$ and testosterone were suppressed. In a second cohort undergoing the same training 1 year later, who were fed an additional $400 \mathrm{kcal}$ per day, LH and testosterone reached near-normal levels despite continued exposure to 
stressors. However, psychological stress was not measured, the key 'stressor' being described by the authors as dietary restriction itself. It is difficult to delineate psychological stress from energy deficiency in a field study without quantification of stress or contemporaneous placebo control.

Reproductive dysfunction seen in exercising women is most likely an adaptation to survive a period of energy deficit by prioritising energy supply for exercise over reproductive function. ${ }^{43-46}$ This is not in one sense a defect as it serves to conserve energy for the individual and can be reduced with sufficient energy intake. ${ }^{18}$ Reduced energy availability, notably below $30 \mathrm{kcal} / \mathrm{kg}$ lean body mass/day, has become the best explanation of exercise-induced reproductive disturbance, especially in lean athletic pursuits. ${ }^{17} 4547$

\section{Ghrelin, leptin and cortisol}

It has been suggested that changes in the anorectic adipokine leptin and orexigenic (appetite stimulating) gut peptide ghrelin mediate reproductive dysfunction during negative energy balance. $^{48}{ }^{49}$ Leptin is released after eating while ghrelin is secreted during fasting. Their primary roles have traditionally been thought to be signalling of satiety and hunger. ${ }^{50}{ }^{51}$ FHA is associated with disproportionately low levels of leptin and high levels of ghrelin. ${ }^{48} 495253$ Welt et $a l^{54}$ successfully used recombinant leptin to restore the menstrual cycle and levels of sex steroids and gonadotropins in women with FHA. These results have been replicated such that it seems that there is a critical leptin threshold below which FHA occurs. ${ }^{55}$

Despite refutation of the exercise stress hypothesis (ie, that activation of the HPA axis solely leads to reproductive dysfunction) in favour of the energy availability hypothesis, ${ }^{41}$ the observation remains that FHA is associated with elevated central and peripheral levels of cortisol. ${ }^{3656}$ Vulliémoz et al ${ }^{57}$ demonstrated this in female rhesus monkeys, in whom negative energy balance and reproductive dysfunction had been induced by ghrelin infusion. LH pulsatility was restored following an infusion of astressin B, a corticotrophin-releasing hormone antagonist. This suggests that normalising cortisol production could reduce the effect of energy availability on reproductive function. ${ }^{57}$

Subsequently, in a cross-sectional analysis of overnight hormone levels in adolescent amenorrhoeic endurance athletes, Ackerman et $a l^{36}$ demonstrated cortisol levels were independently associated with reduced LH pulsatility after correcting for leptin, ghrelin and fat mass. These studies suggest that the action of gut peptides in the reduced energy availability state is mediated through activation of the HPA axis.

It follows that other means of HPA axis activation may also compound reproductive dysfunction, such as psychological stressors observed in military training. ${ }^{5}$ This is illustrated by the use of cognitive behavioural therapy to treat FHA successfully. ${ }^{58}$ Indeed, psychological stress (perceived as threat) can impair food intake. ${ }^{59}$ Since the introduction of functional neuroimaging, we know that the brain is one of the most metabolically active organs in the body. A combination of small synergistic stressors may cause significant reproductive dysfunction in an HPG axis already sensitised by energy deficiency over time. ${ }^{60}$ Thus, recent research findings integrate aspects of the energy availability, stress and body composition hypotheses (leptin is produced in proportion to fat cell mass), demonstrating that complex interactions between hormonal axes, nutrition and energy storage are responsible for reproductive dysfunction.

\section{Female athletic triad}

Much research into reproductive dysfunction has emphasised the female athletic triad (Triad). ${ }^{17}$ The Triad was defined in the 1990 s by the presence of disordered eating (DE), functional amenorrhoea and subsequent premature osteoporosis, ${ }^{61}$ and was subsequently revised to encompass a spectrum of reproductive dysfunction, osteopenia and reduced energy availability (Figure 3). ${ }^{46}$ Cross-sectional studies in various exercising populations (including military trainees) demonstrated a low prevalence of two or more components concurrently. ${ }^{12} \quad 25 \quad 62 \quad 63$ However, such studies were hampered by stringent inclusion criteria and variable definitions of the components (eg, selfreported menstrual regularity vs anovulation determined by serial hormonal measurement).

The Triad includes DE, which refers to abnormal behaviours of limiting food intake to achieve or maintain a desired body image, as opposed to an eating disorder (ED), which may reflect these symptoms but refers to a distinct psychological disorder like bulimia nervosa or anorexia nervosa. ${ }^{64}$

The Triad also encompasses changes in bone mineral density (BMD), the clinical endpoint being osteoporosis. Reduced BMD may be frequently missed as it does not cause symptoms prior to fracture. ${ }^{8} 25$ However, revised definitions may extend to stress fractures, a common overuse injury in military trainees,

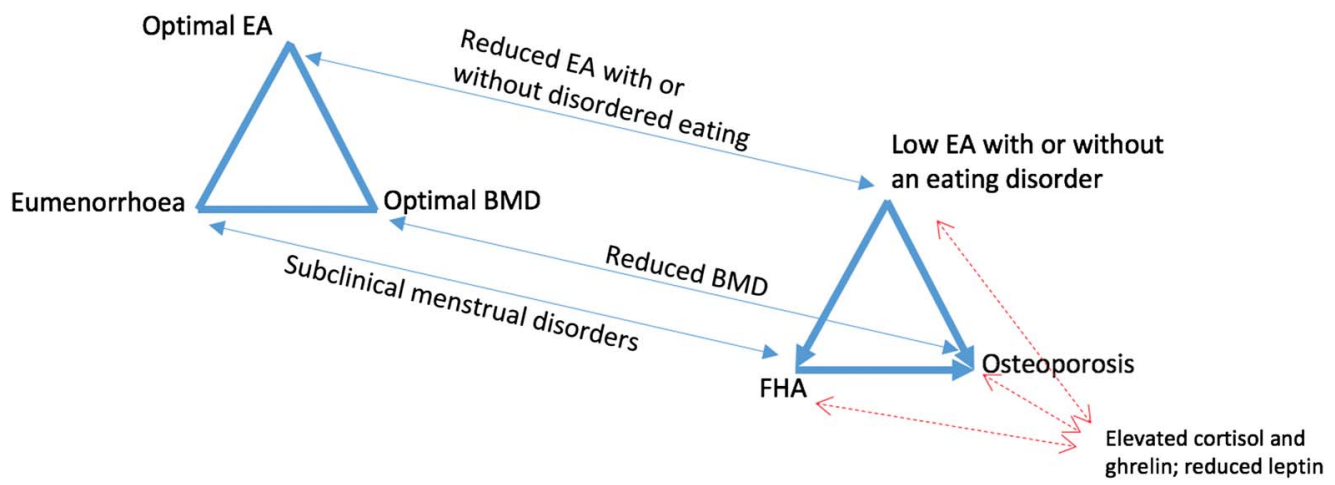

Figure 3 The female athletic Triad. BMD, bone mineral density; EA, energy availability; FHA, functional hypothalamic amenorrhoea. Adapted from the American College of Sports Medicine position stand, 2007. ${ }^{46}$ EA, menstrual function and BMD exist in a clinical spectrum, along which athletes are distributed (thin arrows), An athlete moves either left or right along the spectrum according to exercise and diet practice. Energy availability modulates BMD indirectly via effects on menstrual function and 'directly' via changes in metabolic hormones, notably leptin and ghrelin (thick arrows). All three aspects are associated with changes in the HPA axis and gut hormones (red dashed arrows). BMD, bone mineral density; EA, energy availability; FHA, functional hypothalamic amenorrhoea. 
especially in women. ${ }^{65-67}$ Reproductive dysfunction may possibly increase the risk of stress fractures in female military trainees, but the precise aetiology of stress fractures remains unclear.

Lauder et al's ${ }^{12}$ cross-sectional analysis assessed Triad prevalence in cadets at West Point Military Academy, USA. Only 3\% of cadets demonstrated osteopenia, although the study was limited in its design, since only cadets with menstrual irregularity or at risk of DE underwent BMD assessment, and those on hormonal contraceptives were excluded. However, all cadets were screened for ED. Of significant concern was that $8 \%$ of participants met the criteria for an ED, while $26 \%$ were deemed to be at risk of one, which is comparable with studies in civilian athletes. $^{14}$

The International Olympic Committee recently proposed that, beyond the Triad, relative energy deficiency in sports causes broader physiological impairment, including but not limited to metabolic rate, menstrual function, bone health, immunity, protein synthesis and cardiovascular health in men and women. ${ }^{68}$

\section{OTHER AETIOLOGICAL FACTORS IN MILITARY WOMEN Dietary insufficiency}

The aforementioned studies by Loucks et al and Williams et al demonstrated that the suppression of LH pulsatility following dietary restriction could be reversed when the restriction was lifted. ${ }^{17} 4069$ The degree of energy deficit was recently shown to alter the frequency but not severity of menstrual disturbance in a small cohort undergoing supervised laboratory-based exercise. $^{70}$ The importance of micronutrient content as well as caloric content was suggested from a pragmatically designed study by Andrews et al, ${ }^{71}$ who reported an inverse association between LPD and increased fibre, isoflavane and Mediterranean diet score.

Unintentional dietary restriction is a common component of military training. Dietary restriction may also be intentionally imposed, as noted by Hoyt and Friedl ${ }^{72}$ in their review of field studies in US and Norwegian Rangers, US Marines and others. Their own study was unusual in that they recruited female as well as male soldiers, who endured 7 days of prolonged physical activity, starvation and sleep deprivation, during Ranger training in Norway. ${ }^{73}$ Their findings demonstrated increased usage of fat mass for energy reserve in women compared with men; women lost less weight than men but burned proportionately more fat. The authors did not assess menstrual dysfunction, ghrelin or leptin, and further research is indicated (Table 3). ${ }^{72}$ Energy deficit was also demonstrated in soldiers in barracks, using 24-hour recall in 324 soldiers of 101st Airborne division by Beals et al. ${ }^{74}$ Just $15 \%$ of males and $13 \%$ of females admitted eating the recommended amount of carbohydrate, with no

Table 3 Recommendations for further research on reproductive dysfunction in female military trainees

Topic What is currently known Recommendations

Prevalence of reproductive Prevalence estimates of menstrual dysfunction in athletes vary dysfunction

Prevalence of disordered eating and osteopenia

Influence of androgenisation

Influence of HPA axis and gut peptides

Psychological impact of military training

Long-term effects, injury

Training type

Highly arduous training greatly. ${ }^{14}$ The prevalence in the UK military is not known.

Prevalence estimates of osteopenia and disordered eating in civilian athletes vary dramatically. ${ }^{14}$ The prevalence of all three Triad components combined appears to be low; however, the prevalence in the UK military is not known. ${ }^{8} 12$

Athletes undertaking non-lean sports are predisposed to reproductive dysfunction to a lesser degree than athletes undertaking lean sports. ${ }^{14}$ The mechanism is different, probably involving androgen excess. ${ }^{85}$ Increased androgenisation might be beneficial for bone health. ${ }^{45}$

Cortisol, ${ }^{36}{ }^{86}$ leptin and ghrelin ${ }^{87} 88$ have been implicated in the pathophysiology of reproductive dysfunction in athletes.

Psychological stressors may increase reproductive dysfunction ${ }^{58} 89$ and reduce energy intake. ${ }^{59}$

The effect of exercise associated reproductive dysfunction on long-term child-bearing potential is unknown.

Stress fracture is associated with reduced BMD and female sex. ${ }^{65} 93$

Abrupt training onset increases susceptibility to reproductive dysfunction. ${ }^{95}$

Highly arduous military training (eg, for special forces) can be associated with marked metabolic and endocrine abnormalities. ${ }^{73} 96$
Prospective assessment of changes in ovulation and luteal phase defect should be undertaken by a combination of self-reporting and progesterone assay. ${ }^{47} 76$

Prospective, controlled cohort studies to determine the prevalence of all Triad components in UK military trainees. ${ }^{77}$

Bone health and fat/non-fat mass should be assessed by modern imaging modalities. ${ }^{8} 7879$

Dietary assessment and eating behaviours should use more

sophisticated and validated techniques than 24 -hour recall ${ }^{75} 80-82$ and validated screening questionnaires. ${ }^{83} 84$

Prospective studies characterising the degree of androgenisation in military trainees, associated reproductive changes (functional

hypothalamic amenorrhoea and/or polycystic ovarian syndrome), and whether these are due to training or not.

Studies should aim to determine the relative physical performance of such women, BMD and stress fracture risk compared with controls in the general population

Prospective studies characterising baseline levels of cortisol, ghrelin and leptin against controls

Observing the changes in these hormones in association with changes in measured reproductive function.

Possible psychological covariates of reproductive dysfunction (eg, anxiety, depression, ${ }^{90}$ symptoms of post-traumatic stress disorder, ${ }^{91}$ and resilience ${ }^{92}$ ) should be measured prospectively with reproductive function.

Long-term cohort studies to assess fertility in military trainees versus controls.

Correlates of the risk of injury and illness (bone strength and chronic HPA axis upregulation) ${ }^{94}$ should be studied.

Controlled studies evaluating interventions to reduce the rate of onset, and intensity, of training on reproductive function.

Characterising the reproductive effects of such training in women, as well as energy availability, and implications on BMD.

Long-term follow-up of women in these roles alongside controls in the wider military would reveal any predisposition to injury and poor health. 
significant differences between groups. However as the authors acknowledge, their non-automated, single-interview 24-hour recall method is likely to have contributed to under-reporting. ${ }^{75}$

Not all dietary restriction experienced by military women is imposed by the training regimen. In civilian athletes, DE purportedly contributes to reduced energy availability in association with physical training. It is perhaps surprising that $\mathrm{DE}$, and even overt EDs, were apparently so prevalent in the aforementioned study of West Point cadets. ${ }^{12}$ However, such observations have been made across a wide spectrum of sports, including lean and non-lean activities; the prevalence in endurance, technical and ball game sports $(24 \%, 17 \%$ and $16 \%$, respectively) being significantly greater than controls $(4.6 \% ; \mathrm{p}<0.001) . .^{97} \mathrm{DE}$ is a significant problem in sports medicine, and it is suggested that coaches and physicians routinely look for early evidence in athletes. ${ }^{98}$

Age

The gynaecological age is taken as the number of years after menarche (mean age 12 years). Typically women achieve the highest rate of ovulatory cycles $(94 \%)$ at gynaecological age 12 years, and as female athletes advance beyond this age, the effect of intense training on reproductive function may be attenuated. ${ }^{18} 69$ Many studies demonstrating LPD following reduced energy availability recruit women in their early to mid 20 s, to remove gynaecological maturity as a confounding variable. ${ }^{95}$ However, most military recruits are younger than this, ${ }^{7}$ and a recent, comprehensive review indicates substantially increased vulnerability to reproductive dysfunction in athletes, conferred by gynaecological age $<15$ years. ${ }^{99}$

Adolescence is an important time for bone mineral accrual. ${ }^{100}$ While the majority of bone mass is achieved by age 19 , some cadets may have not achieved peak bone mass by the time of training, ${ }^{99}$ and any losses may have an impact on subsequent peak bone mass. ${ }^{14} 99$

Younger age might also accentuate any impact the psychological element of military training has on reproductive function. Sports that expose adolescents to high levels of psychological stress are associated with hypercortisolaemia and menstrual disruption, ${ }^{99}$ while the developing emotional maturity of adolescence may also confer susceptibility to anxiety about body image and DE. ${ }^{101}$ Women might be particularly affected. ${ }^{100} 101$

\section{Type of physical training}

Military training has traditionally focused on aerobic fitness, although military roles, particularly those of ground close combat, require a combination of strength, power, endurance and aerobic fitness. Most published studies relate to training for lean sports, and there is a paucity of literature describing the effect of strength and power training on female reproductive function. ${ }^{2}$ Training for non-lean sports is associated with increased muscle mass rather than low body mass, and athletes tend to exhibit hyperandrogenism and modest elevations in $\mathrm{LH}$ : FSH ratio (Figure 2). ${ }^{2}{ }^{14}{ }^{95}$ In their military cohort, Lauder et $a l^{12}$ speculate non-lean, high-impact training (eg, loadcarriage) may have significantly increased BMD had their sample size been bigger.

Military training aims to improve submaximal performance for a sustained, non-predefined duration. ${ }^{6}$ It may involve abrupt onset sprinting carrying a load, without a warm-up. Such abrupt exercise onset has been shown to increase propensity to menstrual disturbance, while gradually introduced exercise had dramatically less effect on reproduction. ${ }^{99} 102103$

\section{Other aspects of training}

The psychological challenges of military training include anticipatory stress, time management pressure, conflict between teamwork and leadership roles, and performance evaluation. ${ }^{6} \mathrm{~A}$ combination of physical and mental strain with sleep and food restriction led to marked reductions in LH:FSH and testosterone in male Norwegian soldiers, which improved following administration of gonadotropin-releasing hormone $(\mathrm{GnRH})$ but not a high-caloric diet, suggesting higher suppression of the HPG axis. Temporarily elevated cortisol concentrations were followed by hypocortisolism in the recovery phase. ${ }^{6} 104105$ While derived in men, these observations indicate that the stress of military training could adversely affect female reproductive function.

A study of female US Military personnel revealed the presence of menstrual disorders was strongly associated with increased likelihood of stressful life events compared with matched civilians. ${ }^{89}$ This included amenorrhoea (OR 2.20, 95\% CI 1.08 to 4.50 ) and abnormal cycle length (OR 3.42, 95\% CI 1.12 to 10.50). Women without exposure to a stressful life event were not at significantly altered risk. This study did not examine dietary, metabolic or biochemical parameters.

Other factors associated with military training, which confer additional risk for reproductive dysfunction, include sleep restriction, extreme elemental exposure and musculoskeletal injury. ${ }^{6} 106$ These should not be dichotomised from energy availability. ${ }^{99}$ All can be seen to disrupt the HPA axis and gut peptides, but there is little high-quality, prospective research considering the contributions of such factors to the Triad, especially in the military (Table 3).

Reproductive dysfunction in female athletes during intense exercise is preventable, ${ }^{107}$ suggesting that women should not be excluded per se from arduous training on the basis of their sex. ${ }^{5} \quad 17 \quad 108$ Table 4 summarises potential mitigation

Table 4 Potential future interventions to reduce reproductive dysfunction and its sequelae in military training

\begin{tabular}{|c|c|}
\hline Intervention & Potential benefit \\
\hline $\begin{array}{l}\text { Screening for disordered } \\
\text { eating }\end{array}$ & $\begin{array}{l}\text { With the availability of eating behaviour screening } \\
\text { questionnaires for athletes, }{ }^{83} 84 \text { screening for } \\
\text { components of the Triad may be feasible and } \\
\text { worthwhile. Increasing the ability of military } \\
\text { trainers to identify disordered eating may be } \\
\text { advisable. }\end{array}$ \\
\hline Psychological training & $\begin{array}{l}\text { Dispositional resilience (an attitude to succeed } \\
\text { despite adversity) may protect against menstrual } \\
\text { disturbance and psychological stress and } \\
\text { anxiety }{ }^{592} \text { and with rapid screening available, }{ }^{109} \\
\text { it may be that specialised, targeted input to } \\
\text { military training aimed at fostering this may be of } \\
\text { benefit. }{ }^{83} 92100\end{array}$ \\
\hline $\begin{array}{l}\text { Dietary education or } \\
\text { manipulation }\end{array}$ & $\begin{array}{l}\text { Increased dietary intake can improve luteinising } \\
\text { hormone pulsatility }{ }^{107} \text { and dietary education can } \\
\text { successfully improve dietary intake. }{ }^{110} \mathrm{~A} \\
\text { programme of education might reduce or prevent } \\
\text { reproductive dysfunction in female military } \\
\text { trainees. }\end{array}$ \\
\hline $\begin{array}{l}\text { Protected time allotted for } \\
\text { meals and sleep }\end{array}$ & $\begin{array}{l}\text { Protecting time for eating and rest might prevent } \\
\text { the adverse effects associated with sleep } \\
\text { deprivation }{ }^{96} \text { and improve energy availability. }{ }^{111}\end{array}$ \\
\hline Pretraining standards & $\begin{array}{l}\text { With more information about the nature of } \\
\text { reproductive dysfunction in female military } \\
\text { training and its long-term sequelae, it might be } \\
\text { appropriate to amend selection standards, } \\
\text { identifying women most at risk. }\end{array}$ \\
\hline
\end{tabular}


strategies that, if indicated, might enhance the effectiveness of training and safeguard the long-term well-being of servicewomen. ${ }^{6492100}$

\section{CONCLUSION}

Arduous military training incorporates a multifaceted programme of physical and mental challenges. The energy availability hypothesis, while derived predominantly through small studies in civilian athletes, is putatively key to understanding the aetiology of reproductive dysfunction in female military trainees, influenced by the HPA axis and gut peptides. Hyperandrogenism observed in a subset of athletes may also play a part.

The evidence outlined here warrants further investigation to fully protect the health of female personnel operating in adverse conditions. It is important that military personnel are aware of the potential consequences of serving their country, especially when they are likely to do so before they have reached full physical maturity. The interventions suggested in Table 4 are hypothetical, as the status of female health within UK military training is not currently known. It is not yet clear if such interventions, which may be applicable to athletes, are relevant for military personnel due to the complex physical and mental stimuli of the military training and operational environment.

Contributors RG undertook the literature search, drafted the manuscript and drew the figures. DW, RR, RA and JG provided editorial input to the manuscript.

Competing interests The authors are engaged in planning a prospective study of female endocrine response to UK military training as part of and funded by the UK Defence Women in Ground Close Combat Research Programme.

Provenance and peer review Not commissioned; externally peer reviewed.

\section{REFERENCES}

1 Selye $\mathrm{H}$. The effect of adaptation to various damaging agents on the female sex organs in the rat. Endocrinology 1939;25:615-24.

2 Warren MP, Perlroth NE. The effects of intense exercise on the female reproductive system. J Endocrinol 2001;170:3-11.

3 Hackney A. Effects of endurance exercise on the reproductive system of men: the "exercise-hypogonadal male condition". J Endocrinol Inv 2008;31:932-8.

4 Schneider MB, Fisher M, Friedman SB, et al. Menstrual and premenstrual issues in female military cadets: a unique population with significant concerns. J Pediatr Adolesc Gynecol 1999;12:195-201.

5 Gold MA, Friedman SB. Cadet basic training: an ethnographic study of stress and coping. Mil Med 2000;165:147-52.

6 Booth CK, Probert B, Forbes-Ewan C, et al. Australian army recruits in training display symptoms of overtraining. Mil Med 2006;171:1059-64.

7 Hardoff $D$, Halevy A. Health perspectives regarding adolescents in military service. Curr Opin Pediatr 2006;18:371-5.

8 Mallinson RJ, De Souza MJ. Current perspectives on the etiology and manifestation of the "silent" component of the Female Athlete Triad. Int J Womens Health 2014;6:451-67.

9 Abraham G. The normal menstrual cycle. Endocrine causes of menstrual disorders. Year Book Medical Publishers Chicago, 1978:15-44.

10 Friedl KE, Nuovo JA, Patience TH, et al. Factors associated with stress fracture in young army women: indications for further research. Mil Med 1992;157:334-8.

11 Schneider $\mathrm{MB}$, Bijur $\mathrm{PE}$, Fisher $\mathrm{M}$, et al. Menstrual irregularity in female military cadets: comparison of data utilizing short-term and long-term recall. J Pediatr Adolesc Gynecol 2003;16:89-93.

12 Lauder TD, Williams MV, Campbell CS, et al. The female athlete triad: prevalence in military women. Mil Med 1999;164:630-5.

13 Goodman LR, Warren MP. The female athlete and menstrual function. Curr Opin Obstet Gynecol 2005;17:466-70.

14 Gibbs JC, Williams NI, De Souza MJ. Prevalence of individual and combined components of the female athlete triad. Med Sci Sports Exerc 2013;45:985-96.

15 Slater J, Brown R, McLay-Cooke R, et al. Low energy availability in exercising women: historical perspectives and future directions. Sports Med 2017:47:207-20.

16 De Souza MJ, Miller BE, Loucks AB, et al. High frequency of luteal phase deficiency and anovulation in recreational women runners: blunted elevation in follicle-stimulating hormone observed during luteal-follicular transition. J Clin Endocrinol Metab 1998;83:4220-32.
17 Loucks $A B$. Exercise training in the normal female: effects of low energy availability on reproductive function. In: Constantini $\mathrm{NH}$, Hackney AC, eds. Endocrinology of physical activity and sport. 2nd edn. Humana Press, 2013.

18 Petit MA, Prior JC. Exercise and the hypothalamus. ovulatory adaptations. In: Constantini NH, Hackney AC, eds. Endocrinology of physical activity and sport. 2nd edn. Humana Press, 2013.

19 Wathen NC, Perry L, Lilford RJ, et al. Interpretation of single progesterone measurement in diagnosis of anovulation and defective luteal phase: observations on analysis of the normal range. Br Med J (Clin Res Ed) 1984;288:7-9.

20 De Souza MJ, Toombs RJ, Scheid JL, et al. High prevalence of subtle and severe menstrual disturbances in exercising women: confirmation using daily hormone measures. Hum Reprod 2010;25:491-503.

21 Welch MJ. Women in the Military Academies: US Army (Part 3 of 3). Phys Sportsmed 1989;17:89-96.

22 Anderson JJ. Women's sports and fitness programs at the US Military Academy. Phys Sportsmed 1979;7:72-82.

23 Lauder TD. The female athlete triad: prevalence in military women. Defense Women's Research Program: U.S. Army Medical Research and Materiel Command, 1997. http://www.dtic.mil/cgi-bin/GetTRDoc?AD=ADA330021

24 Torstveit MK, Sundgot-Borgen J. The female athlete triad exists in both elite athletes and controls. Med Sci Sports Exerc 2005;37:1449-59.

25 Barrack MT, Ackerman KE, Gibbs JC. Update on the female athlete triad. Curr Rev Musculoskelet Med 2013;6:195-204.

26 Holt K, Grindlay K, Taskier M, et al. Unintended pregnancy and contraceptive use among women in the U.S. military: a systematic literature review. Mil Med 2011:176:1056-64.

27 Constantini NW, Warren MP. Menstrual dysfunction in swimmers: a distinct entity. J Clin Endocrinol Metab 1995:80:2740-4.

28 Frisch RE, McArthur JW. Menstrual cycles: fatness as a determinant of minimum weight for height necessary for their maintenance or onset. Science 1974;185: 949-51.

29 Hale RW, Kosasa T, Krieger J, et al. A marathon: the immediate effect on female runners' luteinizing hormone, follicle-stimulating hormone, prolactin, testosterone, and cortisol levels. Am J Obstet Gynecol 1983;146:550-6.

30 Loucks AB. Energy availability, not body fatness, regulates reproductive function in women. Ex Sport Sci Rev 2003;31:144-8.

31 Loucks AB, Horvath SM, Freedson PS. Menstrual status and validation of body fat prediction in athletes. Hum Biol 1984;56:383-92.

32 Nagata I, Kato K, Seki K, et al. Ovulatory disturbances. Causative factors among Japanese student nurses in a dormitory. J Adolesc Health Care 1986;7:1-5.

33 Loucks $A B$, Horvath SM. Exercise-induced stress responses of amenorrheic and eumenorrheic runners. J Clin Endocrinol Metab 1984;59:1109-20.

34 Loucks AB, Laughlin GA, Mortola JF, et al. Hypothalamic-pituitary-thyroidal function in eumenorrheic and amenorrheic athletes. J Clin Endocrinol Metab 1992:75:514-18.

35 Loucks AB, Mortola JF, Girton L, et al. Alterations in the hypothalamic-pituitary-ovarian and the hypothalamic-pituitary-adrenal axes in athletic women. J Clin Endocrinol Metab 1989;68:402-11.

36 Ackerman KE, Patel KT, Guereca G, et al. Cortisol secretory parameters in young exercisers in relation to LH secretion and bone parameters. Clin Endocrinol (Oxf) 2013:78:114-19.

37 Winterer J, Cutler GB Jr, Loriaux DL. Caloric balance, brain to body ratio, and the timing of menarche. Med Hypotheses 1984;15:87-91.

38 Wade GN, Schneider JE. Metabolic fuels and reproduction in female mammals. Neurosci Biobehav Rev 1992;16:235-72.

39 Williams NI, Helmreich DL, Parfitt DB, et al. Evidence for a causal role of low energy availability in the induction of menstrual cycle disturbances during strenuous exercise training. J Clin Endocrinol Metab 2001:86:5184-93.

40 Williams NI, Young JC, McArthur JW, et al. Strenuous exercise with caloric restriction: effect on luteinizing hormone secretion. Med Sci Sports Exerc 1995:27:1390-8.

41 Loucks AB, Redman LM. The effect of stress on menstrual function. Trends Endocrinol Metab 2004;15:466-71.

42 Friedl KE, Moore RJ, Hoyt RW, et al. Endocrine markers of semistarvation in healthy lean men in a multistressor environment. J Appl Physiol 2000;88:1820-30.

43 Mallinson RJ, Williams NI, Hill BR, et al. Body composition and reproductive function exert unique influences on indices of bone health in exercising women. Bone 2013:56:91-100.

44 Matzkin E, Curry EJ, Whitlock K. Female athlete triad: past, present, and future. I Am Acad Orthop Surg 2015;23:424-32.

45 Javed A, Kashyap R, Lteif AN. Hyperandrogenism in female athletes with functional hypothalamic amenorrhea: a distinct phenotype. Int I Womens Health 2015;7:103.

46 Nattiv A, Loucks AB, Manore MM, et al. American College of Sports Medicine position stand. The female athlete triad. Med Sci Sports Exerc 2007;39:1867-82 
47 Reed JL, De Souza MJ, Mallinson RJ, et al. Energy availability discriminates clinical menstrual status in exercising women. J Int Soc Sports Nutr 2015;12:11.

48 Weimann E, Blum W, Witzel C, et al. Hypoleptinemia in female and male elite gymnasts. Eur J Clin Inv 1999;29:853-60.

49 Scheid JL, De Souza MJ. Menstrual irregularities and energy deficiency in physically active women: the role of ghrelin, PYY and adipocytokines. Med Sport Sci 2010;55:82-102.

50 Bouassida A, Zalleg D, Bouassida $S$, et al. Leptin, its implication in physical exercise and training: a short review. J Sports Sci Med 2006;5:172.

51 De Souza MJ, Leidy HJ, O'Donnell E, et al. Fasting ghrelin levels in physically active women: relationship with menstrual disturbances and metabolic hormones. J Clin Endocrinol Metab 2004;89:3536-42.

52 Warren MP, Voussoughian F, Geer EB, et al. Functional hypothalamic amenorrhea: hypoleptinemia and disordered eating. I Clin Endocrinol Metab 1999;84: 873-7.

53 Scheid JL, De Souza MJ, Leidy HJ, et al. Ghrelin but not peptide YY is related to change in body weight and energy availability. Med Sci Sports Exerc 2011;43:2063-71.

54 Welt CK, Chan JL, Bullen J, et al. Recombinant human leptin in women with hypothalamic amenorrhea. N Engl J Med 2004;351:987-97.

55 Chou SH, Chamberland JP, Liu X, et al. Leptin is an effective treatment for hypothalamic amenorrhea. Proc Natl Acad Sci USA 2011;108:6585-90.

56 Brundu B, Loucks TL, Adler L, et al. Increased cortisol in the cerebrospinal fluid of women with functional hypothalamic amenorrhea. J Clin Endocrinol Metab 2006;91:1561-5

57 Vulliémoz NR, Xiao E, Xia-Zhang L, et al. Astressin B, a nonselective corticotropin-releasing hormone receptor antagonist, prevents the inhibitory effect of ghrelin on luteinizing hormone pulse frequency in the ovariectomized rhesus monkey. Endocrinology 2008;149:869-74.

58 Pauli SA, Berga SL. Athletic amenorrhea: energy deficit or psychogenic challenge? Ann N Y Acad Sci 2010;1205:33-8.

59 Ulrich-Lai YM, Fulton $S$, Wilson $M$, et al. Stress exposure, food intake and emotional state. Stress 2015;18:381-99.

60 Berga SL. Stress and reprodution: a tale of false dichotomy? Endocrinology 2008;149:867-8

61 Otis CL, Drinkwater B, Johnson M, et al. American College of Sports Medicine position stand. The female athlete triad. Med Sci Sports Exerc 1997;29:i-ix.

62 Khan KM, Liu-Ambrose T, Sran MM, et al. New criteria for female athlete triad syndrome? As osteoporosis is rare, should osteopenia be among the criteria for defining the female athlete triad syndrome? Br J Sports Med 2002;36:10-13.

63 Beals KA, Manore MM. Disorders of the female athlete triad among collegiate athletes. Int I Sport Nutr Exerc Metab 2002;12:281-93.

64 Rumball IS, Lebrun CM. Preparticipation physical examination: selected issues for the female athlete. Clin I Sport Med 2004;14:153-60.

65 Knapik J, Montain SJ, McGraw S, et al. Stress fracture risk factors in basic combat training. Int I Sports Med 2012;33:940-6.

66 Bijur PE, Horodyski M, Egerton W, et al. Comparison of injury during cadet basic training by gender. Arch Pediatr Adolesc Med 1997;151:456-61.

67 Greeves JP. Physiological Implications, performance assessment and risk mitigation strategies of women in combat-centric occupations. J Strength Cond Res 2015;29 (Suppl 11):S94-100.

68 Mountjoy M, Sundgot-Borgen J, Burke L, et al. The IOC consensus statement: beyond the Female Athlete Triad—Relative Energy Deficiency in Sport (RED-S). Br J Sports Med 2014;48:491-7.

69 Loucks $A B$. The response of luteinizing hormone pulsatility to 5 days of low energy availability disappears by 14 years of gynecological age. J Clin Endocrinol Metab 2006:91:3158-64

70 Williams NI, Leidy HJ, Hill BR, et al. Magnitude of daily energy deficit predicts frequency but not severity of menstrual disturbances associated with exercise and caloric restriction. Am J Physiol Endocrinol Metab 2015;308:E29-39.

71 Andrews MA, Schliep KC, Wactawski-Wende J, et al. Dietary factors and luteal phase deficiency in healthy eumenorrheic women. Hum Reprod 2015;30:1942-51.

72 Hoyt RW, Friedl KE. Field studies of exercise and food deprivation. Cur Op Clin Nutr Metab Care 2006;9:685-90.

73 Hoyt RW, Opstad PK, Haugen AH, et al. Negative energy balance in male and female rangers: effects of $7 \mathrm{~d}$ of sustained exercise and food deprivation. $\mathrm{Am}$ J Clin Nutr 2006:83:1068-75.

74 Beals K, Darnell ME, Lovalekar M, et al. Suboptimal nutritional characteristics in male and female soldiers compared to sports nutrition guidelines. Mil Med 2015;180:1239-46.

75 Thompson FE, Subar AF, Loria CM, et al. Need for technological innovation in dietary assessment. J Am Diet Assoc 2010;110:48-51.

76 Ahrens KA, Vladutiu CJ, Mumford SL, et al. The effect of physical activity across the menstrual cycle on reproductive function. Ann Epidemiol 2014;24:127-34.

77 Beals KA, Hill AK. The prevalence of disordered eating, menstrual dysfunction, and low bone mineral density among US collegiate athletes. Int I Sport Nutr Exerc Metab 2006;16:1-23.
78 Christo K, Prabhakaran R, Lamparello B, et al. Bone metabolism in adolescent athletes with amenorrhea, athletes with eumenorrhea, and control subjects. Pediatrics 2008;121:1127-36.

79 Wood PS, Krüger PE, Grant CC. DEXA-assessed regional body composition changes in young female military soldiers following 12-weeks of periodised training. Ergonomics 2010;53:537-47.

80 Rangan AM, Tieleman L, Louie JC, et al. Electronic Dietary Intake Assessment (e-DIA): relative validity of a mobile phone application to measure intake of food groups. Br J Nutr 2016;115:2219-26.

81 Gemming L, Utter J, Ni Mhurchu C. Image-assisted dietary assessment: a systematic review of the evidence. J Acad Nutr Diet 2015;115:64-77.

82 Gemming $L$, Jiang $Y$, Swinburn B, et al. Under-reporting remains a key limitation of self-reported dietary intake: an analysis of the 2008/09 New Zealand Adult Nutrition Survey. Eur J Clin Nutr 2014;68:259-64.

83 Martinsen $\mathrm{M}$, Holme I, Pensgaard AM, et al. The development of the brief eating disorder in athletes questionnaire. Med Sci Sports Exerc 2014;46:1666-75.

84 Melin A, Tornberg AB, Skouby S, et al. The LEAF questionnaire: a screening tool for the identification of female athletes at risk for the female athlete triad. Br J Sports Med 2014;48:540-5.

85 Hagmar M, Berglund B, Brismar K, et al. Hyperandrogenism may explain reproductive dysfunction in olympic athletes. Med Sci Sports Exerc 2009;41:1241-8.

86 Taylor MK, Larson GE, Hiller Lauby MD, et al. Sex differences in cardiovascular and subjective stress reactions: prospective evidence in a realistic military setting. Stress 2014;17:70-8.

87 Scheid JL, De Souza MJ, Hill BR, et al. Decreased luteinizing hormone pulse frequency is associated with elevated 24-hour ghrelin after calorie restriction and exercise in premenopausal women. Am J Physiol Endocrinol Metab 2013;304:E109-16.

88 Ackerman KE, Slusarz K, Guereca G, et al. Higher ghrelin and lower leptin secretion are associated with lower LH secretion in young amenorrheic athletes compared with eumenorrheic athletes and controls. Am J Physiol Endocrinol Metab 2012;302:E800-6.

89 Gordley LB, Lemasters G, Simpson SR, et al. Menstrual disorders and occupational, stress, and racial factors among military personnel. J Occup Environ Med 2000;42:871-81.

90 Marcus MD, Loucks TL, Berga SL. Psychological correlates of functional hypothalamic amenorrhea. Fertil Steril 2001;76:310-16.

91 Lieberman HR, Farina EK, Caldwell J, et al. Cognitive function, stress hormones, heart rate and nutritional status during simulated captivity in military survival training. Physiol Behav 2016;165:86-97.

92 Palm-Fischbacher $\mathrm{S}$, Ehlert U. Dispositional resilience as a moderator of the relationship between chronic stress and irregular menstrual cycle. J Psychosom Obstet Gynaecol 2014;35:42-50.

93 Rauh MJ, Macera CA, Trone DW, et al. Epidemiology of stress fracture and lowerextremity overuse injury in female recruits. Med Sci Sports Exerc 2006;38:1571-7.

94 Stults-Kolehmainen MA, Tuit K, Sinha R. Lower cumulative stress is associated with better health for physically active adults in the community. Stress 2014;17:157-68.

95 Roupas ND, Georgopoulos NA. Menstrual function in sports. Hormones (Athens) 2011;10:104-16.

96 Opstad P. Endocrine and metabolic changes during exhaustive multifactorial military stress. Results from studies during the Ranger training course of the Norwegian Military Academy, 2001. http://www.dtic.mil/dtic/tr/fulltext/u2/ p010649.pdf.

97 Sundgot-Borgen J, Torstveit MK. Prevalence of eating disorders in elite athletes is higher than in the general population. Clin J Sport Med 2004;14:25-32.

98 Ihle $\mathrm{R}$, Loucks $\mathrm{AB}$. Dose-response relationships between energy availability and bone turnover in young exercising women. J Bone Miner Res 2004;19:1231-40.

99 Maïmoun L, Georgopoulos NA, Sultan C. Endocrine disorders in adolescent and young female athletes: impact on growth, menstrual cycles, and bone mass acquisition. J Clin Endocrinol Metab 2014;99:4037-50.

100 Javed A, Tebben PJ, Fischer PR, et al. Female athlete triad and its components: toward improved screening and management. Mayo Clin Proc 2013;88:996-1009.

101 Joy E, Kussman A, Nattiv A. 2016 update on eating disorders in athletes: a comprehensive narrative review with a focus on clinical assessment and management. Br J Sports Med 2016;50:154-62.

102 Bullen BA, Skrinar GS, Beitins IZ, et al. Induction of menstrual disorders by strenuous exercise in untrained women. N Engl J Med 1985;312:1349-53.

103 Rivier C, Rivest S. Effect of stress on the activity of the hypothalamic-pituitary-gonadal axis: peripheral and central mechanisms. Biol Reprod 1991;45:523-32.

104 Opstad PK, Aakvaag A. The effect of sleep deprivation on the plasma levels of hormones during prolonged physical strain and calorie deficiency. Eur J Appl Physiol Occup Physiol 1983;51:97-107.

105 Opstad PK. Androgenic hormones during prolonged physical stress, sleep, and energy deficiency. J Clin Endocrinol Metab 1992;74:1176-83.

106 Opstad PK, Aakvaag A. Decreased serum levels of oestradiol, testosterone and prolactin during prolonged physical strain and sleep deprivation, and the influence of a high calorie diet. Eur J Appl Physiol Occup Physiol 1982;49:343-8. 
107 Lagowska K, Kapczuk K, Friebe Z, et al. Effects of dietary intervention in young female athletes with menstrual disorders. J Int Soc Sports Nutr 2014;11:21.

108 Loucks AB, Thuma JR. Luteinizing hormone pulsatility is disrupted at a threshold of energy availability in regularly menstruating women. I Clin Endocrinol Metab 2003;88:297-311.

109 Campbell-Sills L, Stein MB. Psychometric analysis and refinement of the connordavidson resilience scale (CD-RISC): Validation of a 10-item measure of resilience. J Trauma Stress 2007:20:1019-28.

110 Herzman-Harari S, Constantini N, Mann G, et al. Nutrition knowledge, attitudes, and behaviors of Israeli female combat recruits participating in a nutrition education program. Mil Med 2013;178:517-22.
111 Karl JP, Smith TJ, Wilson MA, et al. Altered metabolic homeostasis is associated with appetite regulation during and following 48-h of severe energy deprivation in adults. Metabolism 2016;65:416-27.

112 Rickenlund A, Thorén M, CarlstroÖm K, et al. Diurnal profiles of testosterone and pituitary hormones suggest different mechanisms for menstrual disturbances in endurance athletes. J Clin Endocrinol Metab 2004;89:702-7.

113 Bermon S, Garnier PY, Hirschberg AL, et al. Serum androgen levels in elite female athletes. J Clin Endocrinol Metab 2014;99:4328-35.

114 Lebrun CM, Joyce SM, Constantini NH. Effects of female reproductive hormones on sports performance. In: Constantini NH, Hackney AC, eds. Endocrinology of physical activity and sport. 2nd edn. Humana Press, 2013. 